\title{
URGENSI TES PSIKOLOGI DALAM LAYANAN PENEMPATAN DAN PENYALURAN DI SMA
}

\author{
Rafsel Tas'adi \\ Program Studi Bimbingan Konseling, Jurusan Tarbiyah STAIN Batusangkar \\ Korespondensi: Jalan Raya Koto Panjang, Sungai Tarab Batusangkar, Sumatera Barat
}

\begin{abstract}
Placement and Distribution service is one of services that are provided in counseling. In senior high school level, this service is provided to place students to their relevant department. Previously, before psychological test was used, placing students into particular departments were only on the basis of their learning achievements. Consequently, higher achievement students were placed into natural science department while the lower ones were placed into social science one. Recently, due to the frequent uses of psychological test in recruiting employees and selecting new college entries, the test is also considered in helping school counselor to place their students into their appropriate department, both in terms of potential and academic achievements. It is expected that placing students into their appropriate any potential problems that the students might encounter in their study can be minimized.
\end{abstract}

Kata kunci: tes psikologi, layanan penempatan dan penyaluran, penjurusan

\section{PENDAHULUAN}

$\mathrm{P}$ embagian jurusan di SMA amatlah penting untuk dilakukan secara tepat dan benar, karena dengan adanya penjurusan ini dapat memberikan arah sejak dini bagi siswa dalam melanjutkan ke pendidikan yang lebih tinggi sehingga dari awal siswa sudah dapat mempersiapkan dirinya dalam pencapaian karirnya di masa yang akan datang. Proses penjurusan yang tepat dan benar akan mempermudah dan membantu siswa dalam mengikuti proses pembelajaran sehingga berbagai kesulitan dapat dihindari. Agar penempatan dan penyaluran siswa dapat dilaksanakan dengan tepat, maka konselor sekolah perlu terlebih dahulu mengenal dan memahami kemampuan/potensi yang dimiliki oleh siswa yang bersangkutan. Salah satu cara yang dapat dipakai untuk mengungkap potensi itu adalah dengan memanfaatkan tes psiklogi.

Pemanfaatn tes psikologi saat ini di sekolah sudah banyak dilakukan, maka yang kita harapkan lagi dalah adanya pemahaman yang sama antara sekolah dengan para orang tua siswa. Sebelum memanfaatkan tes psikologi banyak kejanggalan-kejanggalan yang kita lihat pada saat penjurusan akan dilakukan, misalnya siswa bingung memilih atau menentukan jurusan yang tepat untuk dirinya. Ketika akan dijuruskan, masih banyak siswa yang terpengaruh oleh minat teman-temanya (mereka masih melihat adanya jurusan yang favorit), mereka tidak mampu memahami kemampuan yang mereka miliki, sehingga banyak diantara siswa yang memilih jurusan dengan ikut-ikutan keinginan teman. Disamping ikut-ikutan pilihan teman, minat siswa banyak yang di- 
pengaruhi oleh keinginan orang tuanya. Para orang tua masih memiliki anggapan bahwa jurusan IPA adalah yang paling menentukan masa depan seseorang. Seseorang bisa sukses jika di SMA jurusannya adalah IPA. Barangkali ketika anaknya ditempatkan pada jurusan IPA orang tua merasa bangga karena banyak orang akan melihat anaknya adalah anak yang pintar, siswa merasa bangga, prestisenya menjadi naik. Ini adalah sesuatu anggapan yang sangat keliru!

Selama ini begitulah fenomena yang lazim di lihat, sehingga mamang banyak ditemukan siswa yang menemukan kesulitan akibat dari penjurusan yang tidak tepat karena belum mempertimbangkan kemampuan yang dimiliki. Bahkan ada siswa yang hanya beberapa bulan mengikuti proses pembelajaran setelah pembagian jurusan dilaksanakan ingin pindah pada jurusan yang lain..

Proses penjurusan yang sudah lazim dilaksanakan itu ternyata memiliki kelemahan, artinya jika hanya nilai yang menjadi patokan, sementara tidak selamanya nilai yang diperoleh siswa itu menggambarkan kemampuan akademiknya, maka banyak anak-anak yang telah terlanjur dijuruskan itu mengalami banyak masalah dalam mengikuti proses pembelajaran, terutama bagi mereka yang ditempatkan pada jurusan IPA. Mereka sulit atau bahkan tidak bisa memahami dan mengikuti proses pembelajaran. Hal ini tentu saja disebabkan oleh karena mereka sebenarnya tidak memiliki cukup kemampuan pada jurusan IPA tersebut.

Selama ini jurusan IPA itu adalah jurusan yang selalu paling banyak peminatnya, siswa merasa bangga pada jurusan tersebut, sementara anak-anak pada jurusan selain dari IPA dipandang sebagai anak yang memiliki kemampuan kurang. Sebenarnya yang perlu dipahami oleh semua pihak (orang tua, siswa dan guru) adalah bahwasanya semua jurusan adalah baik, tergantung kemampu- an seseorang, artinya apapun jurusan yang ditetapkan asalkan sesuai/cocok dengan kondisi/kemampuan orang yang bersangkutan, maka jurusan itu dapat dikatakan baik bagi mereka, sebaliknya jurusan itu menjadi tidak baik atau bermasalah jika ditempati oleh siswa yang tidak memiliki kemampuan pada jurusan tersebut. Banyak hal yang mungkin terjadi jika seseorang ditempatkan pada jurusan yang tidak tepat, motivasi belajarnya bisa jadi rendah, banyak menemukan kesulitan atau yang lebih fatal akibatnya anak-anak dapat mengalami tinggal kelas.

Idealnya jurusan yang ditempati oleh seorang siswa haruslah sesuai dengan kemampuan atau potensi yang dimiliki, seperti kecerdasan, bakat dan minat mereka dan tentu saja dengan tidak mengesampingkan hal lain seperti hasil belajar. Potensi yang dimiliki seseorang akan berpengaruh kepada proses yang akan dilaluinya, oleh karena itu perlu diukur. Salah satu cara yang dapat digunakan untuk mengungkap/mengukur potensi seseorang adalah dengan tes psikologi. Saat ini di sekolah-sekolah (SMA) proses penjurusan sudah menggunakan tes psikologi disamping memperhatikan nilai yang diperoleh siswa.

\section{TES PSIKOLOGI UNTUK KEPEN- TINGAN PENJURUSAN}

Berkenaan dengan kegiatan penjurusan di SMA, yang mana setiap siswa akan ditempatkan pada jurusan tertentu yang cocok dengan kemampuan yang dimiliki, sehingga diharapkan siswa yang ditempatkan pada jurusan tertentu dapat menyelesaikan studinya dengan tidak banyak menemukan kesulitan. Untuk itu penjurusan itu haruslah dilakukan secara tepat dan benar. Jurusan yang mereka tempati haruslah yang benar-benar sesuai dengan kemampuan yang dimiliki, tujuannya adalah agar siswa menemukan berbagai bentuk kemudahan dalam 
mengikuti proses pembelajaran sehingga hal-hal yang tidak dinginkan bisa dihindari, misalnya rendahnya motivasi belajar, sulit dalam memahami materi pelajaran, tidak mampu mengerjakan tugas dengan baik, dan berbagai persoalan lainnya. Menempatkan siswa pada jurusan tertentu secara tepat tentu perlu dilakukan dengan mempertimbangkan banyak hal, antara lain: bakat, minat dan tingkat kecerdasannya. Semua ini dapat diperoleh melalui tes psikologi.

Tes psikologi yang biasanya digunakan untuk kepentingan penjurusan sangat beragam. Pengalaman penulis selama menjadi tenaga pelaksana dalam memberikan tes psikologi untuk kepentingan penjurusan di SMA biasanya menggunakan jenis tes yang terdiri dari: Tes IQ untuk mengukur tingkat kecerdasan, Tes bakat Skolastik (kemampuan Verbal dan Numerikal), Tes kemampuan Mekanik, Tes Relasi Ruang, Tes Berfikir Abstrak, Tes Kecepatan dan Ketelitian Klerikal, dan Skala Kecerdasan Emosional.

"Tes IQ adalah salah salah satu bentuk pemeriksaan psikologis yang tujuannya mengukur tingkat kecerdasan seseorang. IQ sendiri merupakan nilai kecerdasan yang menunjukkan tahapan atau kelompok seseorang itu berada pada kategori superior, cerdas, atau rata-rata" (Tim psiko Quantum: 2007: 13).

Tes IQ bukanlah untuk mengukur jumlah atau banyaknya pengetahuan yang dimiliki oleh seseorang atau seberapa banyak yang telah kita simpan dalam otak kita, melainkan untuk mengetahui kapasitas yang kita miliki untuk diketahui. Maksudnya bukan pada apa yang telah dipelajari, tetapi lebih dikhususkan pada kemampuan seseorang untuk belajar. Jadi dengan IQ tertentu dapat diprediksikan seseorang itu akan bisa mengikuti suatu kegiatan dengan mudah dan cepat. "Intelegensi adalah kombinasi sifat-sifat manusia yang mencakup kemampuan untuk memahami hal-hal yang kompleks dan saling berhubungan: semua proses yang terlibat dalam berpikir abstrak, kemampuan menemukan penyesuaian dalam pemecahan masalah dan kemampuan untuk memperoleh kemampuan yang baru" (Conny R. Semiawan dan Djeniah Alim: 2004: 11).

Jika di ilustrasikan seorang anak usia sekolah dasar pada tahap kemampuan rata-rata , secara kognitif berada pada fase berfikir konkrit, tetapi anak yang cerdas telah dapat berfikir abstrak. Artinya jika ia membaca kata "ayam" dalam benaknya tergambar bentuk badan ayam. Anak cerdas juga sangat mudah menemukan pemecahan masalah, karena didukung rasa ingin tahu yang tinggi. "IQ diterima sebagai faktor keturunan dan tetap konstan sepanjang hayat, maka tidak mungkin meningkatkan IQ aktual anda, yang mungkin adalah memperbaiki penampilan anda dalam tes IQ dengan melatih diri dari beragam jenis pertanyaan, dan belajar untuk mengenali tematema dengan berulang-ulang". (Philip Carter \& Ken Russell: 2005: 3)

Hasil tes psikologi akan memberikan data tentang potensi peserta didik yang sangat penting untuk dipamahami. Oleh karena itu pelaksanaannya di sekolah saat ini adalah sesuatu yang sangat tepat. Diharapkan peserta didik akan mampu memahami dirinya dengan baik karena akan membantu siswa dalam menyongsong masa depannya. Menurut Dewa Ketut Sukardi:

"Pemahaman diri secara mandiri mengenai aspek-aspek dirinya, bakatbakatnya, kemapuan-kemampuannya atau potensinya sendiri dengan jelas, nalar, dan logis, hal ini merupakan suatu komponen yang penting dalam mengarahkan, membantu, atau membimbing peserta didik merencanakan masa depan, memilih pekerjaan yang tepat dalam menyongsong masa depan yang lebih cerah" (Dewa Ketut Sukardi: 1997: v) 
Tes psikologi adalah salah satu jenis tes untuk mengukur berbagai potensi yang ada pada diri individu. Oleh karena yang diukur dari tes psikologi ini adalah kemampuan siswa, maka dalam pelaksanaan tes ini proses yang dilalui betulbetul diupayakan sebaik mungkin sesuai dengan prosedur yang ada. Jika dalam pelaksanaan tes ada faktor-faktor lain yang mengganggu maka hal ini akan berdampak kepada tidak validnya hasil tes. "Faktor-faktor yang terkait dengan tes yang mempengaruhi validitas, contohnya pengalaman sebelumnya dalam mengikuti tes, motivasi untuk berhasil dalam tes, hubungan dengan penguji, penekanan berlebihan pada kecepatan dan variable-variabel apapun lainnya yang mempengaruhi kinerja pada tes". (Anne Anastasi:1998: 145).

Anak harus disiplin dengan waktu yang sudah disediakan karena setiap jenis tes memiliki waktu yang berbeda. Semua tes dikerjakan dengan serius, teliti, tidak boleh bekerja sama artinya semua tes harus dikerjakan sendiri. Tenaga tester yang bertanggung jawab penuh terhadap pelaksanaan tes harus bisa memberikan pemahaman kepada siswa sehingga pelaksanaan tes benar-benar sesuai dengan ketentuan. Oleh karena itu sebelum tes dimulai tenaga tester perlu menginformasikan terlebih dahulu semua ketentuan-ketentuan yang harus dipatuhi oleh siswa selama tes dilaksanakan.

Adapun tujuan dari pengukuran psikologis adalah

1. Agar siswa mampu mengenal aspekaspek dirinya (kemampuan, potensi, bakat minat, kepribadian, sikap dan sebagainya)

2. Dengan mengenal aspek-aspek dirinya diharapkan siswa dapat menerima keadaan dirinya secara lebih objektif

3. Membantu siswa untuk mampu mengemukakan berbagai aspek dalam dirinya
4. Membantu siswa untuk dapat mengelola informasi dirinya

5. Membantu siswa agar dapat menggunakan informasi dirinya sebagai dasar perencanan dan pembuatan keputusan masa depan (Dewa Ketut Sukardi: 1988: 8).

Hasil tes akan dijadikan pedoman untuk merekomendasikan pada jurusan apa seorang siswa cocok ditempatkan dan mereka dapat mengikuti pelajaran pada jurusan tersebut tanpa menemukan kesulitan yang berarti. Penempatan pada jurusan tertentu tentu saja dengan memahami potensi dan kemampuan yang terungkap melalui hasil tes. Berdasarkan informasi yang didapatkan dari sekolah, penjurusan yang dilakukan dengan berdasarkan hasil tes ini banyak sekali memberikan manfaat baik kepada siswa, maupun kepada pihak sekolah dan orang tua.

Melalui tes psikologi ini yang diharapkan adalah adanya pemahaman yang tepat terhadap diri peserta didik, baik oleh siswa itu sendiri, oleh guru dan orang tua, sehingga akan banyak memberikan keuntungan. Siswa tidak terbelenggu dengan tuntutan orang tuanya, anak bisa mengukur kemampuan yang dia miliki sehingga tidak mudah terpengaruh oleh pilihan teman-temannya, begitu juga dengan sekolah akan lebih mudah melakukan penjurusan ini.

Sebagaimana yang dijelaskan di atas, tes psikologis yang dilaksanakan selama ini untuk mengukur tingkat kecerdasannya (IQ), dan bakat.serta kecerdasan emosional siswa. Inteligensi erat sekali hubungannya dengan kata intelek yang berarti memahami. "Inteligensi adalah kemampuan untuk berpikir secara abstrak (Terman); Kemampuan untuk menyesuaikan diri dengan lingkungannya (Colvin); ada pula yang mendefinisikan inteligensi dengan intelek plus pengetahuan (Henmon); Teknik untuk memproses informasi yang disediakan 
oleh indra (Hunt)". (Alex Sobur: 2003: 156).

Alfred Binet, dikenal sebagai pelopor dalam menyusun tes inteligensi, mengemukakan pendapatnya mengenai inteligensi sebagai berikut: Inteligensi mempunyai tiga aspek kemampuan, yaitu:

a. Direction, kemampuan untuk memusatkan pada suatu masalah yang harus dipecahkan

b. Adaptacion, kemampuan untuk mengadakan adaptasi terhadap masalah yang dihadapinya atau flesibel dalam menghadapi masalah.

c. Criticism, kemapuan untuk mengadakan kritik, baik terhadap masalah yang dihadapi maupun terhadap dirinya sendiri. (Alex Sobur: 2003: 156).

Bakat adalah salah satu jenis potensi anak yang perlu dikembangkan, oleh karena itu bakat yang dimiliki seseorang sangat perlu penempatan dan penyaluran dengan tepat."Bakat (aptitude) biasanya diartikan sebagai kemampuan bawaan yang merupakan potensi ( $p o$ tential ability) yang masih perlu dikembangkan atau dilatih agar dapat terwujud". (Semiawan dalam Alex Sobur: 2003; 180). Pendapat lain menjelaskan "suatu bakat adalah suatu konsistensi karakteristik yang menunjukkan kapasitas seseorang untuk menguasai suatu pengetahuan khusus (dengan latihan), keterampilan, atau serangkaian respon yang terorganisir" (Ki Fudyartanta: 2004: 1)

Jadi bakat adalah kemampuan yang lebih menonjol atau istimewa daripada yang lain, misalnya seseorang yang mempunyai bakat bahasa Inggris, biasanya akan memiliki kesenangan terhadap bahasa tersebut, lebih cepat memahami dan mudah mempelajarinya, sehingga cakap dalam berbahasa baik secara lisan maupun tertulis. Pada saat mengikuti proses pembelajaran di sekolah biasanya orang yang punya bakat di samping cepat memahami tentu akan diiringi de- ngan memperoleh hasil belajar yang baik.

Dapat di pahami bahwa seseorang yang punya bakat, jika didukung oleh faktor lain/lingkungan maka potensi itu akan mudah dengan cepat berkembangnya, jika dibandingkan dengan orang yang tak punya bakat. Jadi ada juga sebagian dari orang tua, yang tidak memahami akan kemampuan atau bakat anaknya, sementara orang tuanya punya keinginan yang berbeda dengan anaknya maka jelas kondisi tersebut menjadi tidak baik untuk perkembangan seorang anak. Begitu pentingnya memahami akan bakat ini, maka untuk itu perlu dilakukan tes bakat.

Jika pada tes IQ sudah ditentukan standarisasinya, maka "pada tes bakat diberi angka atau nilai dan akan diberi nilai baik jika anda lulus dan nilai rendah jika anda gagal". (Philip Carter \& Ken Russell: 2005: 3). Agar anak dan orang tua sama-sama memahami bakat yang dimilki maka sebaiknya oleh pihak sekolah hasil tes psikologi ini perlu disampaikan kepada orang tua siswa.

\section{PENJURUSAN SISWA DI SMA}

Proses penjurusan di SMA haruslah diperhatikan secara serius dan sungguh-sungguh oleh pihak sekolah. Jika selama ini proses yang dilakukan belum banyak mempertimbangkan aspek dari diri siswa dan hanya mempertimbangkan nilai yang diperoleh saja, maka cara seperti itu belum dianggap tepat, karena ketika siswa mengikuti proses pembelajaran masih banyak siswa yang terkendala, karena keterbatasan dari kemampuannya.

Penjurusan siswa dapat membantu dan mempermudah penentuan arah pendidikan lanjutan dan perencanaan karirnya. Perencanaan karir ke depan memang sudah harus dimulai pada saat pendidikan di SMA, karena setelah itu siswa harus melanjutkan ke Perguruan tinggi. 
Rasa kekhawatiran yang mungkin dialami siswa akan dapat diminimalkan jika penjurusan yang dilakukan di SMA sudah dilakukan dengan tepat.

Pada umumnya jurusan yang ada di tingkat SMA saat ini hanya ada dua, IPA dan IPS walaupun untuk sekolahsekolah tertentu masih ada jurusan Bahasa. Setiap akan penentuan penjurusan, banyak siswa SMA yang menghadapi masalah dalam menetapkan pilihan pada jurusan apa yang akan dipilih. Selama ini anak-anak SMA dalam menentukan pilihan jurusan pada umumnya didasarkan kepada jurusan yang banyak dipilih oleh teman-temanya, atau yang diminati oleh orang tuanya, mereka tidak mengukur kemampuan sendiri, dengan cara seperti ini tentu akan memberikan hasil yang tidak baik. Siswa akan mengalami kesulitan dalam mengikuti pelajaran.

Oleh karena itu sekarang di sekolah dalam hal penentuan jurusan sudah dilakukan dengan memperhatikan dan mempertimbangkan kemampuan dan potensi yang dimiliki oleh masing-masing individu berdasarkan hasil tes psikologi. Jadi memang banyak sekali manfaat yang dirasakan baik oleh sekolah maupun oleh siswa yang bersangkutan dalam hal penjurusan ini berdasarkan pada potensi dan kemampuan dari siswa yang bersangkutan. Untuk itu sangat diharapkan adanya pemahaman dari siswa, guru, dan orang tua. Orang tua tidak perlu lagi memaksakan kepada anak jurusan yang baik itu sesuai dengan keinginan orang tua, akan tetapi adalah yang sesuai dengan kondisi anak.

Dengan telah dilaksanakannya tes psikologi penetapan jurusan yang akan ditetapkan oleh sekolah bagi siswa-siswanya adalah berdasarkan rekomendasi dari hasil tes tersebut disamping juga meperhatikan nilai yang diperoleh oleh anak, serta minatnya. Artinya untuk kondisi saat ini kriteria dalam menetapkan jurusan berdasarkan kepada hasil tes psikologi dan hasil belajarnya. Sebagai gambaran misalnya sekalipun anak berminat pada jurusan tertentu, namun adakalanya berdasarkan hasil tes, diperoleh kemampuannya tidak cukup untuk bisa sukses pada jurusan tersebut, maka dapat saja kita rekomendasikan pada jurusan lain yang sesuai denga potensinya. Jadi akan sangat baik jika minat seseorang juga ditunjang oleh potensi yang dimiliki.

Informasi yang didapatkan dari sekolah, dari hasil tes psikologi ini sangat membantu pihak sekolah dalam menetapkan jurusan. Anak-anak juga merasa puas dan lega dengan jurusan yang ditetapkan untuk dirinya, walaupun kadang-kadang juga terjadi perbedaan antara jurusan yang dia suka dengan jurusan yang direkomendasikan berdasarkan hasil tes.

\section{LAYANAN PENEMPATAN DAN PENYALURAN}

Salah satu jenis layanan dalam konseling adalah "layanan penempatan dan penyaluran". Makna dari layanan ini adalah ditempatkannya seseorang/ individu pada tempat tertentu yang sesuai atau cocok dengan potensi yang dimilikinya atau dengan kata lain Layanan penempatan dan penyaluran membantu individu yang mengalami mismatch (kondisi yang kurang serasi) ditempatkan pada lingkungan yang lebih serasi agar potensi yang ada dapat berkembang secara optimal. (Prayitno: 2004: 2). Berbagai hal bisa terjadi jika salah dalam menempatkan dan menyalurkan seseorang, misalnya jika seseorang tidak memiliki kemampuan dalam bidang bahasa ditempatkan pada jurusan bahasa, dia akan bingung dan menemukan kesulitan.

Betapapun banyaknya peluang untuk mengembangkan kemampuan berbahasanya dia tidak akan dapat mengikuti peluang itu, karena kemampuan yang dimilikinya di bawah kemampuan orang yang punya potensi di situ. Contoh lain misalnya dalam menempatkan 
seorang pegawai. Pekerjaan yang menuntut kemampuan analisis yang tinggi jika ditempati oleh orang yang kerjanya tidak teliti pasti pekerjaannya akan terbengkalai, acak-acakan, bahkan dapat terjadi pegawai tersebut akan meninggalkan begitu saja pekerjaannya.

Di sekolah salah satu penempatan dan penyaluran yang dilakukan adalah penempatan dan penyaluran siswa dalam memilih jurusan yang tepat. Di samping penempatan dan penyaluran siswa dalam penjurusan ada berbagai kegiatan yang perlu dilakukan dengan menempatkan dan menyalurkan secara tepat juga, diantaranya dalam kegiatan ekstra kurikuler, penempatan dalam kelompok belajar, penempatan dalam memposisikan tempat duduk dalam kelas, dan lain sebagainya.

Jika berbicara tentang perlunya penempatan dan penyaluran siswa pada jurusan yang tepat, dalam arti sesuai dengan potensi dan minat yang dimiliki oleh siswa, akan membuat suasana belajar menjadi menyenangkan. Guru akan merasa nyaman, begitupun dengan siswa, materi pelajaran akan mudah dipahami, berbagai kesulitan yang mungkin terjadi akan dapat dihindari.

Jadi jika dikaitkan dengan perlunya menempatkan seseorang pada jurusan yang tepat, sesuai dengan potensinya adalah supaya siswa yang bersangkutan dapat mengikuti semua pelajaran yang ada pada jurusan itu dengan baik, sehingga kemungkinan untuk meraih prestasi itu akan lebih besar. Berdasarkan informasi yang penulis terima dari beberapa sekolah yang melaksanakan tes psikologi untuk menetapkan jurusan yang tepat dengan kondisi peserta didik, maka pada umumnya pihak sekolah merasakan banyak manfaat yang diperoleh. Sekolah tidak lagi menemukan kesulitan pada saat pembagian jurusan yang akan dilakukan, karena dari hasil tes ini akan diketahui potensi siswa, yang mana data tes ini akan menjadi dasar dalam penetapan jurusan.

Disamping kemudahan yang dirasakan oleh sekolah, dari diri siswa sangat memahami akan manfaat dari tes psikologi ini. Siswa dapat mengikuti pembelajaran dengan baik, karena dia merasakan kalau jurusan yang telah ditetapkan oleh sekolah itu sesuai dengan kemampuan yang ia miliki. Manfaat lain yang dirasakan oleh sekolah adalah, pada umumnya siswa dapat menerima pada jurusan yang telah ditetapkan oleh sekolah, tanpa adanya keinginan untuk pindah pada jurusan lain.

\section{PENUTUP}

Tes psikologi sebagai salah satu alat untuk mengukur kemampuan atau potensi yang dimiliki oleh seseorang, sangatlah penting untuk dimanfaatkan dalam memposisikan atau menempatkan seseorang pada tempat tertentu yang tidak hanya dapat dimanfaatkan dalam kegiatan penjurusan saja, melainkan untuk seleksi penerimaan pegawai maupun calon siswa pada tingkat tertentu. Tes psikologi malahan ada digunakan untuk anak-anak TK yang akan masuk SD.

Sebagaimana kita ketahui bahwa masing-masing individu memiliki potensi yang beragam kondisinya, pemahaman terhadap potensi-potensi inilah yang akan membantu peserta didik untuk dapat ditempatkan pada posisi yang tepat, sehingga dapat memberikan manfaat kepada diri siswa, serta memberikan kemudahan bagi sekolah. Terkait dengan kegiatan penjurusan di SMA, maka yang diharapkan dari pihak sekolah adalah:

1. Sekolah harus bisa menempatkan dan menyalurkan siswa pada jurusan yang tepat, sesuai dengan potensi yang dimiliki dengan memanfaatkan hasil tes psikogi.

2. Pemahaman terhadap hasil tes psikologi ini tidak hanya bagi siswa dan sekolah saja, melainkan pihak sekolah 
perlu menyampaikan kepada orang tua tentang kemampuan yang dimiliki anaknya sehingaa semuanya memiliki pemahaman yang sama terhadap kondisi peserta didik

3. Disamping memanfaatkan hasil tes psikologi, hasil belajar yang diperoleh siswa masih tetap menjadi pertimbangan agar penempatan yang dilakukan lebih sempurna lagi.

Dengan memanfaatkan hasil tes psikologi dalam kegiatan penjurusan di SMA ternyata banyak memberikan manfaat kepada siswa. Kesulitan yang di-

\section{DAFTAR RUJUKAN}

Alex Sobur. 2003. Psikologi Umum. CV. Pustaka Setia. Bandung

Anne Annastasi dan Susana Urbina. 1998. Tes Psikologi. PT. Prenhallindo. Jakarta

Conny R. Semiawan dan Djeniah Alim. 2004. Petunjuk Layanan dan Pembinaan Kecerdasan Anak. PT. Remaja Rosdakarya. Bandung.

Dewa Ketut Sukardi. 1997. Analisis Tes Psikologi. Rineka Cipta. Jakarta rasakan pada saat mengikuti proses pembelajaran mungkin tidak terlalu banyak lagi dirasakan, kerena penempatan yang dilakukan sudah berdasarkan potensi yang dimilki sesuai dengan minat, bakat dengan tidak mengabaikan hasil belajar yang diperolehnya. Penjurusan yang tepat akan dapat membantu memperlancar kepada proses pembelajaran, dan memberikan arah yang tepat pula bagi siswa dalam menentukan pilihan untuk melanjutkan ke pendidikan yang lebih tinggi untuk meraih cita-cita yang di inginkan.

Ki Fudyartanta. Tes Bakat dan Perskalaan Kecerdasan. Pustaka Pelajar. Yogyakarta

Prayitno. 2004. Layanan Penempatan dan Penyaluran. Jurusan Bimbingan dan Konseling. Fakultas Ilmu pendidikan. Universitas Negeri Padang.

Philip Carter \& Ken Russell. 2005. Tes Psikometrik. Gaya Media Pratama

Tim Psiko Cuantum. 2007. Psikotes, Mengenal Potensi Diri. CV. Yrama Widya. Bandung. 